\title{
Effect of Dietary Phytobiotics Supplementation On Growth, Serum Biochemical And Chemical Composition Of Nile Tilapia (Oreochromis Niloticus).
}

\author{
H.S. Abdo ${ }^{1}$; M.S. Hassaan ${ }^{2}$; H.D. Tonsy ${ }^{1}$; A.I.M.El-Sayed ${ }^{2}$ \\ ${ }^{1}$ Dept. of By- Product utilisation Research - Animal Production Research Institute, Agricultural Research Center \\ Dokki, Giza, Egypt. \\ ${ }^{2}$ Animal Production Department, Faculty of Agriculture, Benha University, Benha, Egypt. \\ Corresponding Author: hany2010505@yahoo.com
}

\begin{abstract}
e
A Factorial experiment $(2 \times 2)$ was designed to investigate the effect of dietary phytobiotics (onion and thyme powder) and their interaction on growth, feed utilization, serum biochemical and chemical composition of whole Nile tilapia. Four experimental diets were fourmulated; Diet 1 without addition, Diet 2 containing $5.0 \mathrm{~g} \mathrm{~kg}^{-}$ ${ }^{1}$ onion powder, Diet 3 containing $5.0 \mathrm{~g} \mathrm{~kg}^{-1}$ thyme powder, Diet 4 containing $5 \mathrm{~g}$ onion powder $+5 \mathrm{~g}$ thyme powder $\mathrm{kg}^{-1}$ diet. Each treatment group was assigned randomly in duplicate groups of 25 fish $(4.51 \pm 0.01 \mathrm{~g} /$ fish $)$ in 8 plastic tanks for 84 days. The highest values of FBW, WG and SGR (\%), PPV, FR and ER were recorded in Diet 4 but, the highest value of PER was obtained by fish fed diet Diet 2 supplemented with $5 \mathrm{~g} \mathrm{~kg}^{-1}$ diet onion. The best value of FCR was obtained in groups Diet 4. ALT and AST activites were significantly decresed by addition of onion and thyme powder $\left(5 \mathrm{~g} \mathrm{~kg}^{-1}\right.$ diet). Whereas, the lowest total protein, globulin and albumin values were estimated by fish fed on Diet 1 . Supplementation of onion and thyme powder $\left(5 \mathrm{~g} \mathrm{~kg}^{-1}\right.$ diet) in the diets of Nile tilapia significantly effected on $\mathrm{CP}$ of whole - body of tilapia.
\end{abstract}

Keywords : Onion powder, thyme powder, growth, Nile tilapia, phytobiotics

\section{Introduction}

Aquaculture production sector must be increased in order to increase the human population, especially food-fish contribution from capture fisheries is levelled off (FAO, 2018). Feed addidtives have been an increasingly a well-known management technique in aquaculture production systems, where abundant supplements have established an efficiency to enhance the fish immune response or controlling the severity of infections under intensification (MenanteauLedouble et al., 2015; Hassaan et al., 2020).

Phytobiotics feed additives, commonly known as PFAs, are plant origin substances included in the feed of animals at changeable levels with the sole purpose of enhancing animal performance (Hassaan and soltan 2016; Fawole et al., 2020). Herbs, spices and essential oils are major groups of PFAs which serve as sources of bioactive compound (e.g. alkaloid, terpenoid, quinone, polyphenols and flavonoids) as well as are known to have antimicrobial, antifungal, antiviral and antioxidative properties (Yang et al., 2015). Furthermore, It has a wide variety of another properties such as: anti-parasitic, growth promoters, appetite enhancement, stimulant of secretion of bile and digestive enzyme activity (Cristea et al., 2012).

Over the last few years great attention was being given of the effects of inclusion phytobiotics as growth promoters and immune stimulants in aquaculture (Aanyu et al., 2018). Several investigations have been conducted to study the effects of phytobiotics on the growth response of fish fed diets supplemented (Hassaan and soltan 2016; Fawole et al., 2020) for enhancing growth performance and immune status of fish (Al-Sagheer et al., 2018). Rainer and Lea (2015) found that inclusion a mixture of natural growth promoter compounds shows higher growth-boosting power than single phytobiotics because of the symbiotic effects of the interlinkage between bioactive molecules in the different phytobiotics products (Costa et al., 2013).

Onion, Allium cepa is a multipurpose and commonly used traditional spice in foods. It is richly packed with flavonoids, phenolics, saponins and sulphur compounds (Mousavi et al., 2016; Fawole et al., 2020). Onion also contains valuable trace minerals such as selenium, a strong antioxidant (Durigon et al., 2019), and quercetin which play a vital role in the reduction in oxidative stress in fish (Pês et al., 2018).

Thyme is an herbaceous perennial plant belonging to the Lamiaceae family. It includes thymol (44-60\%) and carvacrol (2.2-4.2\%) an essential oil having strong antiseptic properties, rich in antioxidants, potassium, magnesium and vitamins A, $\mathrm{B}$ and $\mathrm{E}$ (Alçiçek, 2011). On other hand thyme has strong antimicrobial, antifungal, antiviral, antiprotozoal, antioxidant activity and digestion stimulating due to its very high contents of thymol (40\%), carvacrol (15\%), p-cymene, eugenol and 4allylphenol (Gültepe et al., 2014; Dorojan et al., 2014).

The use of phytoadditives either singly or in combination has been reported to enhance a numeral of physiological processes in fish. The use of phytoadditives either singly or in combination has been reported to enhance a numeral of physiological processes in fish. In general, afromentioned results recommend that different type of phytobiotics have a 
positive effects on aquatic animals, but need to more investigation to show thier effects on performance responce. The main objective of the current trial was to identify the effect of phytobiotics compounds (onion and thyme) and their interaction on growth and feed efficiency, serum-biochemical indices, and chemical composition of whole Nile tilapia.

\section{Materials and Methods}

\section{Experimental design}

A factorial experiment $(2 \times 2)$ was designed to study the main effects of phytobiotics (onion or thyme) and and their interaction on growth performance, feed utilization, chemical composition of whole-body fish and serum biochemical parameters of Nile tilapia (Oerocromis niloticus).

\section{Fish and culture technique}

Tilapia fingerlings (mono-sex male) were obtained from private farm (El-Sahaba hatshry, Tolmbat 7, Kafr Elsheikh Governorate, Egypt). Fish were acclimated to the experimental conditions for two weeks at Faculty of Agriculture Fish Laboratory, Benha University in cement pond $(3 \times 4 \times 1.25 \mathrm{~m})$. During the acclimation period, fish were fed control feed (30\% crude protein) at three time dialy rate of $3 \%$ of total biomass for 2 weeks to adapt the artificial diet and conditions of the trail. After the acclimatization period the experimental fish were randomly distributed into eight plastic tanks $\left(0.5 \mathrm{~m}^{3}\right.$ for each) representing the four treatments studied with two replicates.

A set of 200 fish of $O$. niloticus L. mono-sex male fingerlings with an average initial body weight of 4.51 $\pm 0.01 \mathrm{~g} /$ fish were used in this trail. Twenty five fish were randomly stocked into each tank with two replications for each treatment. Each tank was supplied with automatic heater (300 watt) to maintain the water temperature $\left(26-28^{\circ} \mathrm{C}\right)$. About $1 / \mathrm{B}$ of water volume in each tank was daily replaced by aerated fresh water after removing the accumulated excreta. A photoperiod of 12-h light, 12-h dark (06:00-18:00 h) was used via fluorescent ceiling lights supplied the illumination.

During the 84-day experimental period, experimental groups of tilapia were hand-fed at a rate of 3\% of body weight three times daily at 09:00 am 12:00 pm and $14 \mathrm{pm}$. Every two weeks, all fish were taken from each tank, then weighted and the amount of feed was adjusted according to the changes in their body weight through out the experimental period. Feed intake was calculated at the end of trial. Water temperature ranged from 26.10 to $28.25^{\circ} \mathrm{C}$; dissolved oxygen (DO) ranged between 5.32 and $6.81 \mathrm{mg} \mathrm{l}^{-1} ; \mathrm{pH}$ values ranged between 8.04 and 8.30 and total ammonia ranged from 0.18 to $0.2 \mathrm{mg} \mathrm{l}^{-1}$ for the different treatments during the entire experimental period (84-days) of the study.

\section{Diets preparation}

Four experimental diets were formulated to contain approximately $30.35 \%$ crude protein and 19.29 MJ kg diet ${ }^{1}$ gross energy, which have been shown to be sufficient to support the optimal growth of $O$. niloticus (Table 1). Diet 1 : Diet 4 were supplemented with $0,5 \mathrm{~g} \mathrm{~kg}^{-1}$ diet onion powder, $5 \mathrm{~g}$ $\mathrm{kg}^{-1}$ diet thyme powder and $5 \mathrm{~g}$ onion powder $+5 \mathrm{~g}$ thyme powder $\mathrm{kg}^{-1}$ diet, respectively.

All dry ingredients were thoroughly mixed with soybean oil, and vitamins and minerals mixture, and then passing the mixed feed through a laboratory pellet mill (2-mm die) in National Institute of Oceanography and Fisheries, Cairo Governorate, Egypt (CMP California Pellet Mill, San Francisco, CA, USA), and stored at $-20{ }^{\circ} \mathrm{C}$ until used.

\section{Growth performance and feed utilization parameters}

Live body weight $(\mathrm{g})$ was determined in all fish from each tank every 14 days during the experiment. Growth performance parameters were measured with the following equations: Condition factor $(\mathrm{K})=\mathrm{W} / \mathrm{L} 3$ $\times 100$, where $\mathrm{W}=$ weight of fish in $\mathrm{g} ; \mathrm{L}=$ total length of fish in $\mathrm{cm}$; weight gain $(\mathrm{WG})=$ final weight (g)-initial weight (g); specific growth rate (SGR, \%) $=(\mathrm{LnW} 2-\mathrm{LnW} 1) / \mathrm{t} \times 100$, where $\mathrm{Ln}=$ the natural $\log$, $\mathrm{W} 1$ = first fish weight, W2 = subsequent fish weight in grams, $\mathrm{t}=$ period in days; feed conversion ratio $(\mathrm{FCR})=$ feed ingested $(\mathrm{g}) /$ weight gain $(\mathrm{g})$; protein efficiency ratio $(\mathrm{PER})=$ weight gain $(\mathrm{g}) /$ protein ingested $(\mathrm{g})$; protein productive value $(\mathrm{PPV}, \%)=$ protein gain of whole fish $(\mathrm{g}) /$ protein intake $(\mathrm{g}) \times 100$; energy retention $(\mathrm{ER}, \%)=$ energy gain $(\mathrm{g}) /($ energy intake) $\times 100$.

\section{Blood Sampling and biochemical indices}

At the end of the experiment, blood samples were collected from the caudal vein of fish in all treatments. The blood sample was allowed to clot at $4{ }^{\circ} \mathrm{C}$ and centrifuged at $3000 \mathrm{rpm}$ for $10 \mathrm{~min}$. The nonhemolyzed serum was collected and stored at $-20^{\circ} \mathrm{C}$ until use. Levels of serum aspartate aminotransferase (AST) and alanine aminotransferase (ALT) were estimmated according to the method described by Reitman and Frankel (1957), and serum creatinine was measured by calorimetric and enzymatic determine cation methods as described by Henry (1974). Total serum protein and albumin were determined according to Henry (1964) and Wotton and Freeman (1982), respectively. However, globulin was calculated by subtracting albumin from total protein according to Coles (1974). 
Table 1. Ingredients $\left(\mathrm{g} \mathrm{kg}^{-1} \mathrm{diet}\right)$ and proximate chemical analysis of the experimental diets (\% on dry matter basis)

\begin{tabular}{|c|c|c|c|c|}
\hline \multirow{2}{*}{ Ingredient } & \multicolumn{4}{|c|}{ Diet NO. (Onion g/Thyme g) } \\
\hline & $\begin{array}{c}\text { Diet } 1 \\
(0 / 0 / 0) \\
\end{array}$ & $\begin{array}{c}\text { Diet } 2 \\
(5 / 0 / 0)\end{array}$ & $\begin{array}{c}\text { Diet } 3 \\
(0 / 5 / 0) \\
\end{array}$ & $\begin{array}{l}\text { Diet } 4 \\
(5 / 5 / 0) \\
\end{array}$ \\
\hline Fish meal & 50 & 50 & 50 & 50 \\
\hline Soybean meal & 470 & 470 & 470 & 470 \\
\hline Corn gluten & 40 & 40 & 40 & 40 \\
\hline Yellow corn & 220 & 220 & 220 & 220 \\
\hline Wheat bran & 160 & 155 & 155 & 150 \\
\hline Soya oil & 40 & 40 & 40 & 40 \\
\hline Onion powder & 0 & 5 & 0 & 5 \\
\hline Thyme powder & 0 & 0 & 5 & 5 \\
\hline Vita $\& \mathrm{M}^{1}$ & 20 & 20 & 20 & 20 \\
\hline \multicolumn{5}{|l|}{ Chemical analysis } \\
\hline Dry matter & 89.33 & 89.30 & 89.11 & 88.17 \\
\hline Crude protein & 30.35 & 30.34 & 30.32 & 30.32 \\
\hline Crude lipid & 7.24 & 7.01 & 6.99 & 7.20 \\
\hline Ash & 4.91 & 4.85 & 4.84 & 4.83 \\
\hline Fiber content & 5.46 & 5.46 & 5.45 & 5.46 \\
\hline $\mathrm{NFE}^{2}$ & 52.04 & 52.34 & 52.40 & 52.19 \\
\hline $\mathrm{GE}^{3}\left(\mathrm{MJ} \mathrm{kg}^{1}\right)$ & 19.29 & 19.21 & 19.21 & 19.29 \\
\hline $\mathrm{TQC}^{4} \mathrm{mg} \mathrm{kg}^{-1}$ & - & 1.93 & - & 1.93 \\
\hline $\mathrm{TFC}^{5} \mathrm{mg} \mathrm{kg}^{-1}$ & - & 2.11 & - & 2.11 \\
\hline Thymol mg kg-1 & - & - & 2.32 & 2.32 \\
\hline p-Cymene mg kg-1 & - & - & 1.16 & 1.16 \\
\hline Carvacol mg kg-1 & - & - & 0.62 & 0.62 \\
\hline
\end{tabular}

${ }^{1}$ Vitamin and mineral mix (mg or g / Kg diet): MnSO4, 40 mg; MgO, 10 mg; K2SO4, 40 mg; ZnCO3, 60 mg; KI, 0.4 mg; CuSO4, $12 \mathrm{mg}$; Ferric citrate, $250 \mathrm{mg}$; Na2SeO3, $0.24 \mathrm{mg}$; Co, $0.2 \mathrm{mg}$; retinol, $40000 \mathrm{IU}$; cholecalciferol, $4000 \mathrm{IU} ; \alpha-$ tocopherolacetate, $400 \mathrm{mg}$; menadione, $12 \mathrm{mg}$; thiamine, $30 \mathrm{mg}$; riboflavin, $40 \mathrm{mg}$; pyridoxine, $30 \mathrm{mg}$; cyanocobalamin, 80 mcg; ;nicotinic acid, $300 \mathrm{mg}$; folic acid, $10 \mathrm{mg}$; biotin, $3 \mathrm{mg}$; pantothenic acid, $100 \mathrm{mg}$; inositol, $500 \mathrm{mg}$; ascorbic acid, 500 mg. ${ }^{2} \mathrm{NFE}$ (Nitrogen free extract) $=100$-(crude protein + lipid + ash + fibre content).

${ }^{3}$ Gross energy calculated using gross calorific values of $23.63,39.52$ and $17.15 \mathrm{kj} / \mathrm{g}$ for protein, fat and carbohydrate, respectively according to Brett (1973).

${ }^{4}$ Total quercetin content $(\mathrm{mg} / \mathrm{kg}) .{ }^{5}$ Total flavonol content $(\mathrm{mg} / \mathrm{kg})$.

\section{Chemical analysis of fish and experimental diets}

The chemical composition of fish and diet samples were determined according to procedures of AOAC (1995). Dry matter (DM) was determined after drying the samples in an oven $\left(105^{\circ} \mathrm{C}\right)$ for $24 \mathrm{~h}$ and Ash by incineration at $550^{\circ} \mathrm{C}$ for $12 \mathrm{~h}$. Crude protein was determined by micro-Kjeldhal method, N\% $\times$ 6.25 (using Kjeltechauto analyzer, Model 1030, Tecator, Höganäs, Sweden) and crude fat by Soxhlet extraction with diethyl ether $\left(40-60^{\circ} \mathrm{C}\right)$.

\section{Statistical analysis}

All data were analyzed by using the software SAS, version 6.03 (SAS 1996). Two-way analysis of variance (Two-way ANOVA) was used to determine whether significant variation existed between the treatments. When overall differences were found, differences between means were tested by Duncan (1955) new multiple range test. One-way ANOVA was used for analyzing the individual effects of phytobiotics (onion powder and thyme powder) and the interaction. All differences were considered significant at $\mathrm{P}<0.05$ and the results are presented as means with pooled standard error of the mean.

\section{Results}

Growth performance of Nile tilapia fingerlings fed experimental diets for 84 days.

The main effects data showed that the dietary addition of onion $\left(5 \mathrm{~g} \mathrm{~kg}^{-1}\right.$ diet $)$ significantly increased the the final body weight (FBW; $\mathrm{P}=0.0001)$, weight gain (WG; $\mathrm{P}=0.0001$ ) and specific growth rate (SGR; $\mathrm{P}=0.0130)$ of Nile tilapia (Table 2 ). Dietary thyme (5 $\mathrm{g} \mathrm{kg}^{-1}$ diet) significantly enhanced the FBW ( $\mathrm{P}=$ $0.0001)$, WG $(\mathrm{P}=0.0002)$ and SGR $(\mathrm{P}=0.0002)$ of Nile tilapia. A significant interaction was observed between onion and thyme for FBW $(\mathrm{P}=0.0038)$, WG $(\mathrm{P}=0.0027)$ and SGR $(\mathrm{P}=0.0045)$. The highest values of FBW (30.71 g), WG (26.22 g) and SGR (2.14) were obtained by fish fed diet supplemented with $5 \mathrm{~g} \mathrm{~kg}^{-1}$ diet onion $+5 \mathrm{~g} \mathrm{~kg}^{-1}$ diet thyme. 
Table 2. Growth performance of Nile tilapia, O. niloticus fed experimental diets for 84 days.

\begin{tabular}{|c|c|c|c|c|c|c|}
\hline \multirow{2}{*}{ Items } & \multicolumn{2}{|c|}{$\begin{array}{l}\text { Phytobiotics } \\
\text { (g kg-1 diet) }\end{array}$} & \multicolumn{4}{|c|}{ Growth performance } \\
\hline & Onion & Thyme & $\begin{array}{l}\text { IBW }^{1} \\
\left(\mathrm{~g} \mathrm{fish}^{-1}\right)\end{array}$ & $\begin{array}{l}\text { FBW }^{2} \\
\left(\text { g fish }^{-1}\right)\end{array}$ & $\begin{array}{l}W_{G}^{3} \\
\left(g_{\text {fish }}^{-1}\right)\end{array}$ & $\begin{array}{l}\text { SGR } \\
\left(\% \text { day }^{-1}\right)\end{array}$ \\
\hline D1 & 0 & 0 & 4.50 & $28.64^{\mathrm{f}}$ & $24.13^{\mathrm{f}}$ & $2.06^{\mathrm{d}}$ \\
\hline D2 & 5 & 0 & 4.54 & $29.87^{e}$ & $25.32^{\mathrm{e}}$ & $2.10^{\mathrm{c}}$ \\
\hline D3 & 0 & 5 & 4.49 & $30.29^{d}$ & $25.82^{\mathrm{e}}$ & $2.13^{\mathrm{cb}}$ \\
\hline D4 & 5 & 5 & 4.51 & $30.71^{\mathrm{d}}$ & $26.22^{\mathrm{d}}$ & $2.14^{\mathrm{b}}$ \\
\hline Pooled SE & & & 0.01 & 0.14 & 0.15 & 0.01 \\
\hline \multicolumn{7}{|c|}{ ANOVA (P value) } \\
\hline Onion & & & 0.450 & 0.0001 & 0.0001 & 0.0130 \\
\hline Thyme & & & 0.473 & 0.0001 & 0.0002 & 0.0002 \\
\hline Onion $\times$ Thyme & & & 0.062 & 0.0038 & 0.0027 & 0.0045 \\
\hline
\end{tabular}

Duncan multiple range test was conducted for individual means only if there was a significant interaction (ANOVA: P $<0.05$ ). Means followed by the same letter are not significantly different.

$\mathrm{IBW}^{1}=$ initial body weight $\left(\mathrm{g} \mathrm{fish}^{-1}\right) ; \mathrm{FBW}^{2}=$ final body weight $\left(\mathrm{g} \mathrm{fish}^{-1}\right) ; \mathrm{WG}^{3}=$ weight gain $\left(\mathrm{g} \mathrm{fish}^{-1}\right) ; \mathrm{SGR}^{4}=$ specific $^{-1}$ growth rate $\left(\%\right.$ day $\left.^{-1}\right)$.

\subsection{Feed intake and feed utilization of Nile tilapia fed experimental diets for 84 days.}

The main effects of onion or thyme and their interaction on feed intake (FI), feed conversion ratio (FCR), protein efficiency ratio (PER) and protein productive value (PPV) of Nile tilapia are summarized in Table 3. The main effects data showed that the dietary addition of onion $\left(5 \mathrm{~g} \mathrm{~kg}^{-1}\right.$ diet $)$ significantly increased the FI $(\mathrm{P}=0.0001)$ and PER $(\mathrm{P}=0.0300)$ of Nile tilapia, but no significantly effected on FCR (P = $0.1355), \mathrm{PPV}(\mathrm{P}=0.7506), \mathrm{FR}(\mathrm{P}=0.2751)$ and $\mathrm{ER}$ $(\mathrm{P}=0.3827)$. Dietary thyme $\left(5 \mathrm{~g} \mathrm{~kg}^{-1}\right.$ diet $)$ significantly enhanced the FI $(\mathrm{P}=0.0001)$ and FCR $(\mathrm{P}$ $=0.0201)$ of Nile tilapia, but no significantly effected on PER ( $\mathrm{P}=0.5994)$, PPV $(\mathrm{P}=0.3779), \mathrm{FR}(\mathrm{P}=$ 0.7542) and $\operatorname{ER}(\mathrm{P}=0.4978)$. No significant differences were observed between onion and thyme for FI $(\mathrm{P}=0.6108)$, FCR $(\mathrm{P}=0.9471)$, PER $(\mathrm{P}=$ 0.9472), PPV ( $\mathrm{P}=0.4878), \mathrm{FR}(\mathrm{P}=0.8492)$ and $\mathrm{ER}$ $(\mathrm{P}=0.3189)$. The highest FI (37.02 g), PPV (43.15 $\%)$, FR (77.02\%) and $\operatorname{ER}(27.86 \%)$ values were obtained by fish fed diet (D4) supplemented with $5 \mathrm{~g}$ $\mathrm{kg}^{-1}$ diet onion $+5 \mathrm{~g} \mathrm{~kg}^{-1}$ diet thyme. The best FCR value (1.41) was recorded by fish of D4. Furthermore, the highest value of PER was recorded by fish fed of D2 and D4 respictively.

Table 2. Growth performance of Nile tilapia, O. niloticus fed experimental diets for 84 days

\begin{tabular}{|c|c|c|c|c|c|c|}
\hline \multirow{2}{*}{ Items } & \multicolumn{2}{|c|}{$\begin{array}{c}\text { Phytobiotics }\left(\mathrm{g} \mathrm{kg}^{-1}\right. \\
\text { diet) }\end{array}$} & \multicolumn{4}{|c|}{ Growth performance } \\
\hline & Onion & Thyme & $\begin{array}{c}\text { IBW }^{1} \\
\left(\text { g fish }^{-1}\right)\end{array}$ & $\begin{array}{c}\text { FBW } \\
\left(\text { g fish }^{-1}\right)\end{array}$ & $\begin{array}{c}\mathbf{W G}^{3} \\
\left(\mathrm{~g} \mathrm{fish}^{-1}\right)\end{array}$ & $\begin{array}{c}\text { SGR } \\
\left(\% \text { day }^{-1}\right)\end{array}$ \\
\hline D1 & 0 & 0 & 4.50 & $28.64^{\mathrm{f}}$ & $24.13^{\mathrm{f}}$ & $2.06^{\mathrm{d}}$ \\
\hline D2 & 5 & 0 & 4.54 & $29.87^{\mathrm{e}}$ & $25.32^{\mathrm{e}}$ & $2.10^{\mathrm{c}}$ \\
\hline D3 & 0 & 5 & 4.49 & $30.29^{d}$ & $25.82^{\mathrm{e}}$ & $2.13^{\mathrm{cb}}$ \\
\hline D4 & 5 & 5 & 4.51 & $30.71^{\mathrm{d}}$ & $26.22^{\mathrm{d}}$ & $2.14^{\mathrm{b}}$ \\
\hline Pooled SE & & & 0.01 & 0.14 & 0.15 & 0.01 \\
\hline \multicolumn{7}{|l|}{ ANOVA (P value) } \\
\hline Onion & & & 0.450 & 0.0001 & 0.0001 & 0.0130 \\
\hline Thyme & & & 0.473 & 0.0001 & 0.0002 & 0.0002 \\
\hline Onion $\times$ Thyme & & & 0.062 & 0.0038 & 0.0027 & 0.0045 \\
\hline
\end{tabular}

Duncan multiple range test was conducted for individual means only if there was a significant interaction (ANOVA: P $<0.05$ ). Means followed by the same letter are not significantly different.

$\mathrm{IBW}^{1}=$ initial body weight $\left(\mathrm{g} \mathrm{fish}^{-1}\right) ; \mathrm{FBW}^{2}=$ final body weight $\left(\mathrm{g} \mathrm{fish}^{-1}\right) ; \mathrm{WG}^{3}=$ weight gain $\left(\mathrm{g} \mathrm{fish}^{-1}\right) ; \mathrm{SGR}^{4}=$ specific growth rate $\left(\%\right.$ day $\left.^{-1}\right)$.

3. Blood biochemical of Nile tilapia, $O$. niloticus fed experimental diets for 84 days.

3.1. Alanine aminotransferase (ALT, $\mathrm{UL}^{-1}$ ) and aspartateaminotransferase (AST, $\left.\mathrm{UL}^{-1}\right)$
Data of onion or thyme and their interaction on alanine aminotransferase (ALT) and aspartate aminotransferase (AST) of Nile tilapia are showed in Table 4. The main effects data showed that the dietary 
addition of onion $\left(5 \mathrm{~g} \mathrm{~kg}^{-1}\right.$ diet $)$ significantly decreased the ALT $(P=0.0222)$ and AST $(P=0.0371)$ of Nile tilapia. A significant differences were observed in the $\operatorname{ALT}(\mathrm{P}=0.0020)$ and AST $(\mathrm{P}=0.0236)$ of Nile tilapia as affected by thyme $\left(5 \mathrm{~g} \mathrm{~kg}^{-1}\right.$ diet $)$. ALT value was significantly $(\mathrm{P}=0.0005)$ affected by the interaction between onion and thyme, but no significantly $(\mathrm{P}=$ 0.1129) effected on AST.

The lowest (best) level of ALT was recorded by fish of D4 which fed diet supplemented with $5 \mathrm{~g} \mathrm{~kg}^{-1}$ diet onion $+5 \mathrm{~g} \mathrm{~kg}^{-1}$ diet thyme. Furthermore the best level of AST was recorded by fish of D3 which fed diet supplemented with thyme $5 \mathrm{~g} \mathrm{~kg}^{-1}$ diet.

\subsection{Serum of total protein, albumin and globulin}

The main effects of onion orthyme and their interaction on serum of total protein, albumin and globulin of Nile tilapia are noted in Table 4. No significant $(\mathrm{P}>0.05)$ differences were found in serum of total protein, albumin and globulin values as affected by the main effects of

Table 4. Biochemical indices of Nile tilapia fingerlings fed experimental diets for 84 days.

\begin{tabular}{|c|c|c|c|c|c|c|c|}
\hline \multirow{3}{*}{ Items } & \multicolumn{2}{|c|}{ Phytobiotics ( kg $^{-1}$ diet) } & \multirow{2}{*}{\multicolumn{5}{|c|}{ Blood biochemical }} \\
\hline & \multirow{2}{*}{ Onion } & \multirow{2}{*}{ Thyme } & & & & & \\
\hline & & & $\begin{array}{l}\mathbf{A L T} \\
\left(\mathbf{U L}^{-1}\right)\end{array}$ & $\begin{array}{l}\text { AST } \\
\left(\mathbf{U L}^{-1}\right)\end{array}$ & $\begin{array}{l}\text { TP } \\
\left(\mathrm{g} \mathrm{dl}^{-1}\right)\end{array}$ & $\begin{array}{l}\mathbf{A L} \\
\left(\mathrm{g} \mathrm{dl}^{-1}\right)\end{array}$ & $\begin{array}{l}\text { GL } \\
\left(\mathrm{g} \mathrm{dl}^{-1}\right)\end{array}$ \\
\hline D1 & 0 & 0 & $39.50^{\mathrm{a}}$ & $17.50^{\mathrm{a}}$ & $2.54^{\mathrm{d}}$ & $1.38^{\mathrm{e}}$ & $1.15^{\mathrm{c}}$ \\
\hline D2 & 5 & 0 & $38.50^{\mathrm{ab}}$ & $12.00^{\mathrm{c}}$ & $3.36^{\mathrm{a}}$ & $1.90^{\mathrm{a}}$ & $1.46^{\mathrm{ab}}$ \\
\hline D3 & 0 & 5 & $33.50^{\mathrm{c}}$ & $11.00^{\mathrm{c}}$ & $2.90^{\mathrm{cb}}$ & $1.75^{\mathrm{b}}$ & $1.15^{\mathrm{c}}$ \\
\hline D4 & 5 & 5 & $31.00^{\mathrm{d}}$ & $12.50^{\mathrm{c}}$ & $2.74^{\mathrm{cd}}$ & $1.47^{\mathrm{ed}}$ & $1.27^{\mathrm{cb}}$ \\
\hline \multicolumn{3}{|c|}{ Pooled SE } & 0.661 & 1.131 & 0.069 & 0.028 & 0.072 \\
\hline \multicolumn{8}{|c|}{ ANOVA (P value) } \\
\hline \multicolumn{3}{|l|}{ Onion } & 0.0222 & 0.0371 & 0.2494 & 0.2138 & 0.5712 \\
\hline \multicolumn{3}{|c|}{ Thyme } & 0.0020 & 0.0236 & 0.9262 & 0.6556 & 0.7593 \\
\hline \multicolumn{3}{|c|}{ Onion $\times$ Thyme } & 0.0005 & 0.1129 & 0.0065 & 0.0536 & 0.2542 \\
\hline
\end{tabular}

Duncan multiple range test was conducted for individual means only if there was a significant interaction (ANOVA: P $<0.05$ ). Means followed by the same letter are not significantly different.

$\mathrm{ALT}=$ Alanine aminotransferase; $\mathrm{AST}=$ Aspartate aminotransferase .

$\mathrm{TP}=$ Total protein; $\mathrm{AL}=$ Albumin; $\mathrm{GL}=$ Globulin .

onion $\left(5 \mathrm{~g} \mathrm{~kg}^{-1}\right.$ diet $)$ and thyme $\left(5 \mathrm{~g} \mathrm{~kg}^{-1}\right.$ diet $)$. A significant interaction was observed between onion and thyme for serum of total protein $(\mathrm{P}=0.0065)$, albumin $(\mathrm{P}=0.0536)$ but no significantly effected on globulin $(\mathrm{P}=0.2542)$. The highest values of total protein, albumin and globulin were recorded by fish of D2 which fed diet supplemented with onion $\left(5 \mathrm{~g} \mathrm{~kg}^{-1} \mathrm{diet}\right)$. Whereas, the lowest total protein, globulin and albumin values were estimated by fish fed on control diet (D1).

\subsection{Proximate analysis of Nile tilapia, $O$. niloticus fed experimental diets for 84 days.}

Data of onion or thyme and their interaction on proximate analysis; dry matter (DM), crude protein (CP), lipid and ash content of whole - body of Nile tilapia are showed in Table 5. With respect to the effect of dietary addition of onion, no significant differences were observed in DM $(\mathrm{P}=0.0678), \mathrm{CP}(\mathrm{P}=0.1401)$, lipid $(\mathrm{P}=0.4986)$ and ash content $(\mathrm{P}=0.1835)$ of fish fed diet supplemented with onion $\left(5 \mathrm{~g} \mathrm{~kg}^{-1}\right.$ diet $)$. As described in Table 5, inclusion of thyme $\left(5 \mathrm{~g} \mathrm{~kg}^{-1}\right.$ diet $)$ did not significant affected on DM ( $\mathrm{P}=0.1438), \mathrm{CP}(\mathrm{P}$ $=0.0910)$, lipid $(\mathrm{P}=0.7995)$ and ash content $(\mathrm{P}=$ 0.6913 ) of Nile tilapia. With regard to the effected of interaction between onion and thyme, no significant differences were found in $\mathrm{DM}(\mathrm{P}=0.1474), \mathrm{CP}(\mathrm{P}=$ $0.0637)$ and lipid $(\mathrm{P}=0.9025)$, but significantly effected on ash content $(\mathrm{P}=0.0284)$. The highest value of DM was recorded by fish fed the control diet, while, the lowest one was noted in fish fed diet (D2) supplemented with $5 \mathrm{~g} \mathrm{~kg}^{-1}$ diet onion. Furthermore, the highest value of CP was recorded by fish fed of both D2 and D4. The highest values of lipid and ash content were recorded by fish fed diet (D2) supplemented with $5 \mathrm{gkg}^{-1}$ diet onion, while, the lowest values of lipid were noted by fish fed of both D1 and D3 but, the lowest value of lipid was noted by fish fed of D1. 
Table 5. Proximate analysis of Nile tilapia, O. niloticus fed experimental diets for 84 days.

\begin{tabular}{|c|c|c|c|c|c|c|}
\hline \multirow{3}{*}{ Items } & \multicolumn{2}{|c|}{ Phytobiotic (g kg ${ }^{-1}$ diet) } & \multirow{2}{*}{\multicolumn{4}{|c|}{$\begin{array}{l}\text { Chemical composition } \\
\text { (\% on dry matter basis) }\end{array}$}} \\
\hline & \multirow{2}{*}{ Onion } & \multirow{2}{*}{ Thyme } & & & & \\
\hline & & & DM & Protein & lipid & Ash \\
\hline D1 & 0 & 0 & $27.50^{\mathrm{a}}$ & $56.97^{\mathrm{h}}$ & $22.12^{\mathrm{ab}}$ & $12.54^{\mathrm{ed}}$ \\
\hline D2 & 5 & 0 & $25.94^{\mathrm{cb}}$ & $58.80^{c}$ & $22.89^{\mathrm{a}}$ & $15.42^{\mathrm{a}}$ \\
\hline D3 & 0 & 5 & $26.47^{\mathrm{ab}}$ & $58.37^{\mathrm{e}}$ & $22.12^{\mathrm{ab}}$ & $13.28^{\text {cde }}$ \\
\hline D4 & 5 & 5 & $26.73^{\mathrm{ab}}$ & $58.86^{\mathrm{b}}$ & $22.70^{\mathrm{a}}$ & $13.75^{\text {cde }}$ \\
\hline \multicolumn{3}{|c|}{$\begin{array}{l}\text { Pooled SE } \\
\text { ANOVA (P value) }\end{array}$} & 0.2067 & 0.320 & 0.1808 & 0.1964 \\
\hline \multicolumn{3}{|l|}{ Onion } & 0.0678 & 0.1401 & 0.4986 & 0.1835 \\
\hline \multicolumn{3}{|c|}{ Thyme } & 0.1438 & 0.0910 & 0.7995 & 0.6913 \\
\hline \multicolumn{3}{|c|}{ Onion $\times$ Thyme } & 0.1474 & 0.0637 & 0.9025 & 0.0284 \\
\hline
\end{tabular}

Duncan multiple range test was conducted for individual means only if there was a significant interaction (ANOVA: P < 0.05). Means followed by the same letter are not significantly different.

$\mathrm{DM}=$ Dray mater.

\section{Discussion}

1. Growth responses and feed efficiency of Nile tilapia fed experimental diets

In the present study body weight and feed utilization were improved in fish group that received diet supplemented with mixture of $5 \mathrm{~g} \mathrm{~kg}^{-1}$ diet onion $+5 \mathrm{~g} \mathrm{~kg}^{-1}$ diet thyme; however, the addition of onion or thyme herb alone also significantly $(\mathrm{P}<0.05)$ improved the growth performance of Nile tilapia fish. This improvement of body weight gains may be found due to the active materials in the herbal plants which increased the efficiency of utilization of feed, resulting in enhanced growth. Thymol and carvacrol from thyme are active material in the plant, which are considered as appetizer and stimulating of digestion, in addition to their antimicrobial activity against intestinal bacteria resulting of enhancing health status and growth (Jameel $\boldsymbol{e}$ t al., 2014). Thyme powder improved growth rate and survival rate in common carp diet ALsafah and AL-Faragi, (2017). The highest weight gain (WG) and the specific growth rate (SGR) were showed in Sobaity sea bream (Sparidentex hasta) which fed diets containing 1\% thyme (Jahanjoo et al., 2018). Diet supplemented with thyme improved growth and nutrient utilization in the European sea bass (Dicentrarchus labrax) (Yılmaz et al., 2012). Dicu et al. (2013) reported that thyme supplemented diets significantly improved growth performance of Stellate Sturgeon (Acipenser stellatus Pallas, 1771) and their optimal growth was obtained at $2 \%$ thyme. Also, Zaki et al. (2013) stated that $O$. niloticus fed with thyme (1\% and $2 \%$ ) levels had a positive effect on growth performance. On the other hand, Dorojan et al. (2014) found that stellate sturgeon (Acipenser stellatus) fed diet supplemented with $2 \%$ thyme (Thymus vulgaris) improved weight gain, specific growth rate, feed conversion ratio and protein efficiency ratio. Diet supplemented with 2,500 and 5,000 ppm dietary thyme powder improved FW, SGR and WG in Nile tilapia (El-Gendy et al., 2010). Thyme powder improved final weight in Nile tilapia diet Antache et al., (2013). Costa et al. (2013) and Rainer and Lea, (2015) argued that combinations of phytobiotics products may have stronger growthpromoting effects than individual phytobiotics products. The mechanisms exerted with phytobiotics additives such as onion powder on growth performance are still little understood in fish and crustacean species (Cho and Lee, 2012; Akrami $\boldsymbol{e t}$ al., 2015). In addition, rainbow trout fed diets contained a mixture of thymol and carvacrol improved $(P<0.05)$ feed efficiency and growth (Giannenas $\boldsymbol{e t}$ al., 2012). On the contrary, no impacts of phytobiotics on growth and feed efficiency (Kim et al., 2013; Takaoka et al., 2016). The potential reasons for superiority of the combination phytobiotics than other treatments may be due to the benefit effect of phytobiotics together than when it was used individually. Moreover, phytobiotics may enhances the probiotic function through offer appropriate substrate for intestinal biota action. Thus, the combination of the onion and thyme could exert a beneficial effect on growth and feed efficacy, as presented in this study.

Blood biochemical parameters of Nile tilapia fed experimental diets

1. Alanine aminotransferase aspartate aminotransferase

ALT and AST as liver enzymes are important indicators for liver health and function through controlling transferring amino group function of alpha-amino acids to alpha-keto acids. In the present study, onion and thyme supplementation alone markedly improved the AST and ALT enzymes, this shows that the supplementation of onion or thyme did not cause any hepatic cell alteration. In this context, Fawole et al. (2020) noted that AST of catfish fed diet supplemented with onion powder was significantly $(\mathrm{P}<$ $0.05)$ lower than control group. (Shalaby et al., 2006) showed that the activities of ALT and AST of Nile tilapia decreased significantly with increasing level of 
Allium sativum. Antiradical and antioxidant characteristics of onion powder containing flavonoids led to prevent lipid peroxidation of cell membranes and finally suppress the release of liver damage enzymes such as AST and ALT into plasma (Akrami et al., 2015; Cho and Lee, 2012). Thyme essential oil (Thymus vulgaris) supplementation improved the activity of ALT and AST of gibel carp, Carassius auratus gibelio compared to the control fish group (Zadmajid and Mohammadi, 2017). Similarly, Jahanjoo et al. (2018) noted that diet supplemented with mixture of herbal medicine as $1 \%$ Garlic $+1 \%$ Ginger $+1 \%$ thyme improved the activities of ALT and AST of Sobaity Sea bream (Sparidentex hasta) Fry. On the other hand, Akrami et al. (2015) and Cho and Lee (2012) revealed that dietary onion powder did not show any significant effect on the activities of ALP, ALT and AST in Beluga Huso huso and Olive flounder, Paralichthys olivaceus respectively. To date, there is no exact clarification on how synergistic effect of phytogenic to stimulate the aminotransferase enzymes in aquatic animals, thus, future studies on the current topic are therefore recommended.

\section{Total protein, albumin and globulin}

Proteins are the most important compounds in serum and their concentration are considered as basic index for fish health status (Misra et al., 2006; Alexander et al., 2011).

Supplementation of thyme powder in Cyprinus carpio L. diets significantly enhanced in serum of total protein and globulin, but no significantly enhanced in albumin (ALsafah and Faragi, 2017). Supplementation of onion powder in goldfish diets had no significant $(\mathrm{P}>0.05)$ effect on serum of total protein (Cho and Lee, 2012). Also, no significant ( $P$ $>0.05$ ) difference was found in serum of total protein, albumin and total cholesterol of Common Carp (Cyprinus carpio) fed diet supplemented with onion powder (Mousavi et al., 2016). Gulec, et al 2013 found that the total protein, albumin and albumin globulin ratio in rainbow trout fed thyme and fennel were higher than control. Similar findings were reported by Sahu et al. (2007) a mixture of $1 \%$ Garlic $+1 \%$ Ginger $+1 \%$ thyme supplementation, increased serum of total protein and albumin in treated of Sobaity Sea Bream (Sparidentex hasta) Fry compared to the control fish group (Jahanjoo et al., 2018).

Results of serum biochemical indices give an indicator for improved the response of health status of fish. Furthermore, the significant impact noticed in the current study might be due to the combined synergistic and therapeutic effect of onion and thyme. More researches are wanted to supply knowledge about the effect of dietary photobiotics on serum biochemical parameters.

\subsection{Proximate analysis of whole fish of Nile tilapia fed experimental diets}

In the present study, chemical composition of Nile tilapia did not affect by individual supplementation of onion or thyme and their interaction, while the crude protein was higher in fish fed diet supplemented with the combination of $5 \mathrm{~g}$ onion $\mathrm{kg}^{-1}+5 \mathrm{~g}$ thyme $\mathrm{kg}^{-1}$. Dietary onion powder supplementation caused in a decreased crude protein and crude lipid of catfish compared with the control (Fawole et al., 2020). The lower whole-body lipid content observed in fed onion or thyme powder could be attributed to the phytogenic capability in inducing lipid catabolism for optimum utilization by the fish. Onion can induce endogenous lipogenesis and increase lipid catabolism in rat (Kumari and Augusti, 2007). Also, Waweru et al. (2019) noted that Nile tilapia fed pawpaw seed powder had a significant decreased whole-body lipid composition. Farrag et al. (2013) and Waweru et al. (2019) noted that the whole-body constituent depletion often results in tissue hydration of inverse relationships between muscle lipids and moisture content.

\section{Referances}

Aanyua, M., Betancora, M. B. and Monroiga, O. 2018. Effects of dietary limonene and thymol on the growth and nutritional physiology of Nile tilapia (Oreochromis niloticus). Aquaculture, 488: 217- 226.

Akrami, R., Gharaei, A., Mansour, M. R., and Galeshi, A. 2015. Effects of dietary onion (Allium сера) powder on growth, innate immune response and hemato-biochemical parameters of beluga (Huso huso Linnaeus, 1754) juvenile. Fish and Shellfish Immunology, 45: 828-834.

Alçiçek, Z. 2011. The effects of thyme (Thymus vulgaris L.) oil concentration on liquid-smoked vacuum-packed rainbow trout (Oncorhynchus mykiss Walbaum, 1792) fillets during chilled storage Food Chemistry, 128 (3): 683-688.

Alexander, C., Sahu, N. P., Pal A. K. and Akhtar, M. S. 2011. Haemato-immunological and stress responses of Labeo rohita (Hamilton) fingerlings: effect of rearing temperature and dietary gelatinized carbohydrate. J. Anim. Physiol. Anim. Nutr., 95: 653-663.

ALsafah, A. H. and AL-Faragi, J. K. A. 2017. Influence of Thyme (Thymus Vulgaris) As Feed Additives on Growth Performance and Antifungal Activity on Saprolegnia Spp. In Cyprinus carpio L. Journal of American Science, 14(2): 48-54.

Al- Sagheer, A.A., Mahmoud, H.K., Reda, F.M., Mahgoub, S.A. and Ayyat, M.S., 2018. Supplementation of diets for Oreochromis niloticus with essential oil extracts from lemongrass (Cymbopogon citratus) and geranium (Pelargonium graveolens) and effects on growth, intestinal microbiota, antioxidant and immune activities. Aquaculture Nutrition, 24(3): pp.10061014. 
Antache, A., Cristea, V., Grecu, I., Dediu, L., Mirela, M., Sandita, I., Mihai, P. S. 2013. The effects of some phytobiotics on biochemical composition of oreochromis niloticus meat reared in a recirculating aquaculture system. Animal Science and Biotechnologies, 2013: 46 (1): 238243.

AOAC, 1995. In: Cunni, P.A. (Ed.), Official Methods of Analysis of the Association Official Analytical Chemists, Vol. 1, 16th ed. AOAC International, Arlington, USA, p. 1298.

Brett, J. R. 1973. Energy expenditure of Sockeye salmon Oncorhynchus nerka, during sustained performance. Journal of the Fish Research Board of Canada, 30: 1799-1809.

Cho, S. H. and Lee, S. M. 2012. Onion powder in the diet of the olive flounder, Paralichthys olivaceus: effects on the growth, body composition, and lysozyme activity. Journal of the World Aquaculture Society, 43: 30-38.

Coles, E. H. 1974. Plasma proteins. In: Veterinary clinical pathology, 2nd edition. W.B. Saunders Co., Philadelphia, Pennsylvania, USA: 558-560.

Costa, L. B., Luciano, F. B., Miyada, V. S. and Gois, F. D. 2013. Herbal extracts and organic acids as natural feed additives in pig diets. South African Journal of Animal Science, 43: 181-193.

Cristea, V., Antache, A., Grecu, I., Docan, A., Dediu, L., And Mocanu, M. 2012. The use of phytobiotics in aquaculture. Lucrări Ştiinţifice - Seria Zootehnie, vol. 57: $250-255$.

Dicu, M. D., Cristea, V., Dediu, L., Docan, A., Grecu, I. R., and Vasilean, I. 2013. Effects of Stocking Density on Growth and Hematological Profile of Early Juveniles Stellate Sturgeon ( $A$. stellatus Pallas, 1771) Reared in a " Flow-Through " Production System. Scientific Papers: Animal Science and Biotechnologies, 46(2): 250-257.

Dorojan, O. G., Placinta, S. and Petrea, S. 2014. The influence of some phytobiotics (thyme, seabuckthorn) on growth performance of stellate sturgeon (A. stellatus, Pallas, 1771) in an industrial recirculating aquaculture system. Animal Science and Biotechnologies, 47 (1): 205-210.

Duncan, M. B. 1955. Multiple ranges and multiple Ftests. Biometrics, 11: 1-42.

Durigon, E., Kunz, D., Peixoto, N., Uczay, J., and Lazzari, R. 2019. Diet selenium improves the antioxidant defense system of juveniles Nile tilapia (Oreochromis niloticus L.). Brazilian Journal of Biology, 79(3): 527-532.

EL-Gendy, K. S., Aly, N. M., Mahmoud, F. H., Anter Kenawy, A. and El-Sebae, A. H. 2010. The role of vitamin $\mathrm{C}$ as antioxidant in protection of oxidative stress induced by imidacloprid. Food and Chemical Toxicology, 48: 215-221.

FAO 2018. Food Agriculture Organization of the united nations: The State of World Fisheries and Aquaculture Meeting the Sustainable Development Goals.
Farrag, F., Khalil, F., Mehrim, A., and Refaey, M. (2013). Pawpaw (Carica papaya) seeds powder in Nile tilapia (Oreochromis niloticus) diets: Growth performance, survival, feed utilization, carcass composition of fry and fingerlings. Journal of Animal and Poultry Production, Mansoura University, 4(6), 363-379.

Fawole, F. J., Adeoye, A. A., Tiamiyu, L. O., Samuel, F. C., Omosuyi, O. M. and Amusa, M. T. 2020. Dietary combination of pawpaw seed and onion peel powder: Impact on growth, haematology, biochemical and antioxidant status of Clarias gariepinus. Aquaculture Research, 51(7): 2903-2912.

Giannenas, I., Triantafillou, E., Stavrakakis, S., Margaroni, M., Mavridis, S., Steiner, T. and Karagouni, E. 2012. Assessment of dietary supplementation with carvacrol or thymol containing feed additives on performance, intestinal microbiota and antioxidant status of rainbow trout (Oncorhynchus mykiss). Aquaculture, 350: pp.26-32.

Gulec, A. K., Danabas, D., Ural, M., Seker, E., Arslan, A. and Serdar, O., 2013. Effect of mixed use of thyme and fennel oils on biochemical properties and electrolytes in rainbow trout as a response to Yersinia ruckeri infection. Acta Veterinaria Brno, 82(3): pp.297302.

Gültepe, N., Bilen, S., Yılmaz, S., Güroy, D. and Aydın, S. 2014. Effects of herbs and spice on health status of tilapia (Oreochromis mossambicus) challenged with Streptococcus iniae, ACTA VET. BRNO, 83: 125-131.

Hassaan, M. S., Mohammady, E. Y., Adnan, A. M., Abd Elnabi, H. E., Ayman,M. F., Soltan, M. A., and El-Haroun, E. R. 2020. Effect of dietary protease at different levels of malic acid on growth, digestive enzyme, and haematoimmunologicaln responses of Nile tilapia, fed fish meal free diets. Aquaculture, 522: 735124.

Hassaan, M. S., and Soltan, M. A. 2016. Evaluation of essential oil of fennel and garlic separately or combined with Bacillus licheniformis on the growth, feeding behaviour, hemato-biochemical indices of Oreochromis niloticus (L.) fry. J. Aquac. Res. Dev, 7: 422-429.

Henry, R. J. 1964. Colorimetric determination of total protein. Clinical Chemistry. Harper and Row Publ., New York, USA, p. 181.

Henry, R. J. 1974. Clinical Chemistry Principles and Techniques, 2nd ed. Harper and Row. Publ., New York, p. 525.

Jahanjoo, V., Yahyavi, M., Akrami, R. and Bahri, A. H. 2018. Influence of Adding Garlic (Allium sativum), Ginger (Zingiber officinale), Thyme (Thymus vulgaris) and Their Combination on the Growth Performance, Haemato- Immunological Parameters and Disease Resistance to Photobacterium damselae in Sobaity Sea Bream 
(Sparidentex hasta) Fry. Turkish Journal of Fisheries and Aquatic Sciences, 18: 633-645.

Jameel YJ, Abed A, Al-Shimmary F. 2014. Influence of Adding Garlic and Thyme and their Combination on Immune Response and Some Blood Parameters in Broiler. Scientia, 2: 102-106.

Kim, E; Choi, Y; Jang, J. and Park, T. 2013. Carvacrol protects against hepatic steatosis in mice fed a highfat diet by enhancing SIRT1-AMPK signaling. Evidence- Based Complementary and Alternative Medicine, Article ID 290104, 10 pages.

Kumari, K., and Augusti, K. T. 2007. Lipid lowering effect of S-methyl cysteine sulfoxide from Allium cepa Linn in high cholesterol diet fed rats. Journal of Ethnopharmacy, 109, 367-371.

Menanteau-Ledouble, S., Krauss, I., Santos, G., Fibi, S., Weber, B., El-Matbouli, M., 2015. Effect of a phytogenic feed additive on the susceptibility of Onchorhynchus mykiss to Aeromonas salmonicida, Dis. Aquat. Org. 115, $57-66$.

Misra, S., Sahu, N. P., Pal, A. K., Xavier, B., Kumar, S. and Mukherjee, S. C. 2006. Pre- and post-challenge immune-haematological changes in Labeo rohita juveniles fed gelatinised or nongelatinised carbohydrate with n-3 PUFA. Fish Shellfish Immunol, 21: 346-356.

Mousavi, E., H. Mohammadiazarm, S. M. and Ghatrami, E. R. 2016. Effects of inulin, savory and onion powders in diet of juveniles carp Cyprinus carpio (Linnaeus 1758) on gut microflora, immune response and blood biochemical parameters. Turkish Journal of Fisheries and Aquatic Sciences, 16: 831-838.

Pês, T. S., Saccol, E. M. H., Londero, É. P., Bressan, C. A., Ourique, G. M., Rizzetti, T. M., Pavanato, M. A. 2018. Protective effect of quercetin against oxidative stress induced by oxytetracycline in muscle of silver catfish. Aquaculture, 484: 120-125.

Rainer, A. and Lea, H. 2015. Secondary plant compounds are more than essential oils. Lohmann Information, 49, (1).

Reitman, S. and S. Frankel. 1957. Colorimetric determination of glutamic oxaloacetic and glutamic pyruvic transaminases. Journal of Clinical Pathology, 28: 56-59.

Sahu, S., Das, B. K., Pradhan, Y., Mohapatra, B. C., Mishra, B. K. and Sarangi, N. 2007. Effect of
Mangifera indica kernel as a feed additive on immunity and resistance to Aeromonas hydrophila in Labeo rohita fingerlings. Fish and Shellfish Immunology, 23 (1): 109-118.

SAS 1996. SAS Procedure Guide version 6.12 Ed. SAS Institute Inc., Cary, NC, USA.

Shalaby, A.M., Khattab, Y.A., and Abdel Rahman, A.M. 2006. Effects of garlic (Allium sativum) and chloramphenicol on growth performance, physiological parameters and survival of Nile Tilapia immunostimulants for fish. Journal of Ethnopharamacology, 88, 99-106.

Takaoka, O., Ji, S. C., Ishimaru, K., Lee, S. W., Jeong, G. S., Biswas, A. and Takii, K. 2016. Dietary medicinal herbs and enzyme treated fish meal improve stress resistances and growth performance at early juvenile stage of red sea bream Pagrus major. Aquaculture Research, 47: 390-397.

Waweru, J. N., Raburu, P. O., and Odhiambo, E. A. 2019. Gonad Histology, Proximate Composition and Growth Efficiency of Nile Tilapia Fed with Pawpaw (Carica papaya) Seeds Powder. Asian Journal of Fisheries and Aquatic Research, 1-9.

Wotton, I. D. and Freeman, H. 1982. Micro analysis in Medical Biochemistry. Churchill, New York, USA.

Yang, C; Kabir-Chowdhury, M. A., Hou, Y. and Gong, J. (2015). Phytogenic compounds as alternatives to infeed antibiotics: Potentials and challenges in application. Pathogens, 4: 137-156.

Yılmaz S, Ergün S and Türk N 2012. Effects of herbal supplements on growth performance of sea bass (Dicentrarchus labrax): Change in body composition and some blood parameters. J BioSci Biotech, 1(3): 217-222.

Zadmajid, V., Mohammadi, C. 2017. Dietary thyme essential oil (Thymus vulgaris) changes serum stress markers, enzyme activity, and hematological parameters in gibel carp (Carassius auratus gibelio) exposed to silver nanoparticles. Iranian Journal of Fisheries Sciences, 16(3): 1063-1084.

Zaki, M. A.; Labib, E. M.; Nour, A. M.; Tonsy, H. D. and Mahmoud, S. H. 2013. Effect of some medicinal plants diet on mono sex Nile tilapia (Oreochromis niloticus), growth performance, feed utilization and physiological parameters. Asia-Pacific Chemical, Biological and Environmental Engineering Society, 220-227. 


\section{تأثير إضافة الفيتوبيوتك على النمو والصفات الكيماوية للام والتحليل الكيماوى لأسماك البلطى النيلى. هانى صبحى عبده , , محمد شعبان حسان² , هيام دسوقى تونسى 1 , عبدالكريم إبرهيم محمد السيد² 1 قسم بحوث الإستفادة من المخلفات - معهد بحوث الإنتاج الحيوانى - مركز البحوث الزراعية. 2 قسم الإنتاج الحيوانى - كلية الزراعة - جامعة بنها.}

أجريت تجربة عاملية 2 × 2 لدراسة تأثير إضافة الفيتوبيوتيك (مسحوق البصل بمعدل 0,0 , 5 جم/كجم علف, ومسحوق الزعتر بمعدل 0,0 , 5 جم/كجم علف) والتداخل بينهما على النمو , والإستفادة من الغذاء, ومقاييس الدم, والتحليل الكيماوى لجسم أسماك البطى النيلى. تم تكوين أربع علائق

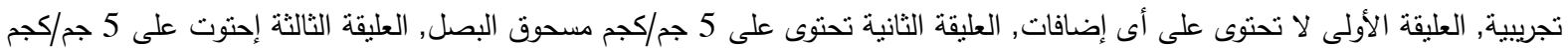

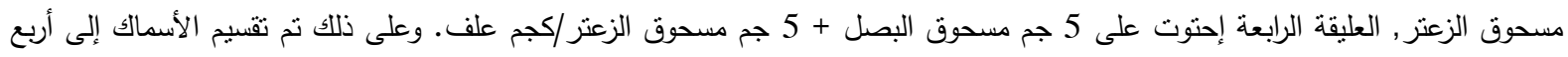

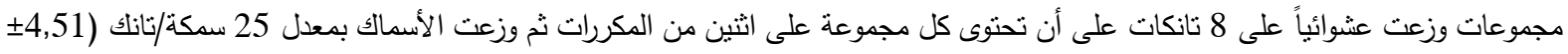
0,01 جم/ سككة) لددة 84 يوم. سجلت العليقة الرابعة أعلى قيمة لكلا من متوسطات الونات الوزن النهائى, ووزن الجسم المكتسب, أفضل قيمة لكفاءة

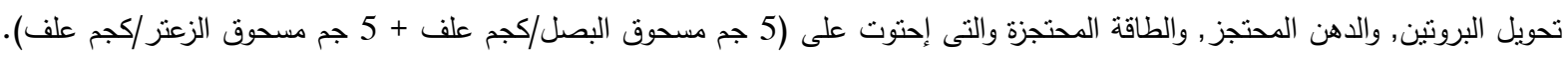

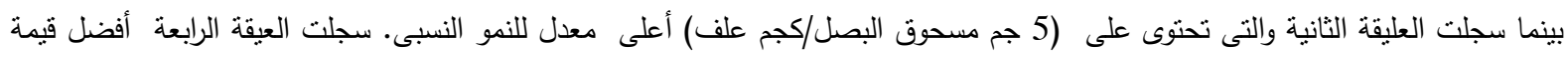

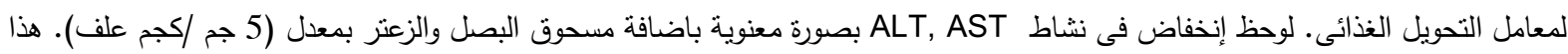
بالاضافة الى العيقة الثانية أظهرت أعلى قيمة لكلا من متوسطات نسبة البروتين الكلى, والألبيومين والجلوبيولين والتى تغذت على على عليقة تحتوى

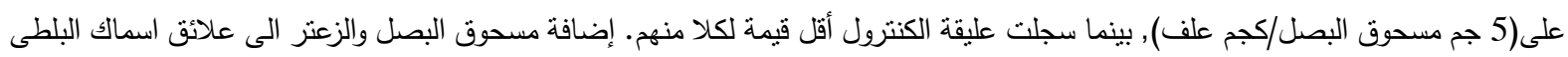
النيلى كان له تأثير إيجابى معنوى على نسبة البروتين فى أجسام أسماك البلطى. 